\title{
The effect of whole cottonseed and processing of canola on the milk production and composition of first lactation Holstein heifers
}

\author{
L.J. Erasmus ${ }^{1 \#}$, P.C. Haasbroek ${ }^{1}$ and J.B.J. van Ryssen ${ }^{2}$ \\ ${ }^{1}$ Agricultural Research Council - ANPI, Private Bag X2, Irene, 0062 \\ ${ }^{2}$ Dept Animal and Wildlife Sciences, University of Pretoria, Pretoria, 0001 \\ "e-mail:lourens@idpi1.agric.za
}

\section{Introduction}

The use of whole oilseeds such as whole cottonseed (WCS) to increase the energy density of dairy cattle diets is common practice today. Research has shown that certain varieties of canola (previously called rapeseed) are well adapted to the Western Cape and the area planted is expanding fast. Canola has a similar protein content when compared to WCS but contains more than double the amount of fat (Macgregor, 1994). There are, however still some questions regarding the need to process canola and the effects thereof on milk composition.

\section{Materials and Methods}

Thirty first lactation Holstein heifers were used in randomised block design with the heifers being blocked on their average production from d $17-\mathrm{d} 20$ post partum. After blocking the heifers were changed from a standard fresh cow diet to one of three experimental diets for a period of $60 \mathrm{~d}$. The experimental diets were similar in chemical composition (17.0\% CP 11.4 MJ ME/kg DM), were based on lucerne hay, oat hay and maize meal with the main difference the inclusion of oilseeds namely (i) $10 \%$ WCS, (ii) $10 \%$ crushed canola or iii) $10 \%$ whole canola seed. The canola was processed using a rollermill. Milk production and DMI intake were measured daily, milk samples were taken weekly for fat, protein and MUN analysis, and body condition and body weight was monitored every two weeks. Additional milk samples were taken on days 30, 40 and 50 post partum for analysis of the milk fatty acid profile. An ANOVA was performed using Genstat 5.

\section{Results and Discussion}

The effect of feeding WCS, crushed canola or whole canola seed on the productivity and milk fatty acid profiles of first lactation Holstein heifers is shown in Tables1 and 2 respectively.

Table 1: Effect of oilseed supplementation on productivity of first lactation Holstein heifers

\begin{tabular}{|c|c|c|c|c|}
\hline \multirow[b]{2}{*}{ Item } & \multicolumn{3}{|c|}{ Diet $^{1}$} & \multirow[b]{2}{*}{$\mathrm{P}=$} \\
\hline & $\mathrm{WC}$ & WCS & $\mathrm{CC}$ & \\
\hline Milk (kg/d) & 29.4 & 28.5 & 29.0 & 0.78 \\
\hline DMI $(\mathrm{kg} / \mathrm{d})$ & 20.2 & 20.5 & 20.3 & 0.91 \\
\hline Fat $(\%)$ & $3.84^{\mathrm{a}}$ & $3.47^{\mathrm{b}}$ & $3.95^{\mathrm{a}}$ & 0.01 \\
\hline Protein (\%) & 3.08 & 3.01 & 3.05 & 0.55 \\
\hline MUN (mg\%) & 14.2 & 14.2 & 15.8 & 0.24 \\
\hline $\mathrm{BCS}$ & 2.9 & 3.0 & 2.7 & 0.15 \\
\hline Body weight (kg) & 547 & 553 & 549 & 0.97 \\
\hline
\end{tabular}

${ }^{1} \mathrm{WC}=$ whole canola; $\mathrm{WCS}=$ whole cottonseed; $\mathrm{CC}=$ crushed canola; ${ }^{\mathrm{ab}} \mathrm{P}<0.05$

Dry matter intake and milk production did not differ between treatments. Heifers receiving the canola diets produced milk with a higher fat \% ( $\mathrm{P}<0.05)$. Body weight and body condition score were not affected by treatment. Supplementation with crushed canola decreased the concentration of medium chain and increased long chain fatty acids in milk fat when compared to heifers receiving the whole cottonseed diet $(\mathrm{P}<0.05)$. 
Table 2: Effect of oilseed supplementation on milk fatty acids profiles

\begin{tabular}{|c|c|c|c|c|}
\hline \multirow{2}{*}{$\begin{array}{c}\text { Fatty acids } \\
(\mathrm{g} / 100 \mathrm{~g})\end{array}$} & \multicolumn{3}{|c|}{$\operatorname{Diet}^{1}$} & \multirow[b]{2}{*}{$\mathrm{P}=$} \\
\hline & WC & WCS & $\mathrm{CC}$ & \\
\hline C14:0 & 6.23 & 6.78 & 5.83 & 0.59 \\
\hline C16:0 & $25.0^{\mathrm{ab}}$ & $27.2^{\mathrm{a}}$ & $23.1^{\mathrm{b}}$ & 0.01 \\
\hline C18:0 & $16.6^{\mathrm{b}}$ & $16.3^{\mathrm{b}}$ & $20.5^{\mathrm{a}}$ & 0.01 \\
\hline C18:1 & 40.1 & 36.1 & 39.5 & 0.28 \\
\hline $\mathrm{C} 18: 2$ & $4.31^{\mathrm{a}}$ & $4.57^{\mathrm{a}}$ & $3.53^{\mathrm{b}}$ & 0.01 \\
\hline $\mathrm{C} 18: 3$ & 0.65 & 0.55 & 0.43 & 0.10 \\
\hline C18 total & 61.6 & 57.6 & 64.0 & 0.07 \\
\hline $\mathrm{C} 16: \mathrm{C} 18$ total & $0.41^{\mathrm{a}}$ & $0.48^{\mathrm{b}}$ & $0.36^{\mathrm{a}}$ & 0.02 \\
\hline
\end{tabular}

${ }^{1} \mathrm{WC}=$ whole canola; $\mathrm{WCS}=$ whole cottonseed $\mathrm{CC}=$ crushed canola; ${ }^{\text {ab }} \mathrm{P}<0.05$

Although the general recommendation is that canola seeds should be ground or crushed, processing did not influence production parameters in this study.This is in agreement with other results (Schingoethe, 1995). At higher intakes (> $25 \mathrm{~kg} \mathrm{DM} / \mathrm{d}$ ), however it might be necessary to process canola due to the higher ruminal outflow rate. At higher outflow rates processing would probably increase the efficiency of utilisation of nutrients. The high concentration of $\mathrm{C} 16: 0$ and C14:0 in milk continues to be a concern to many in the medical community. Thus, increasing the $\mathrm{C} 18: 0$ and $\mathrm{C} 18: 1$ fatty acids at the expense of $\mathrm{C} 14: 0$ and $\mathrm{C} 16: 0$ is considered desirable from a human health perspective. It also offers the benefit of a softer butter (Kennelly \& Glimm, 1998). Substituting cottonseed for canola resulted in a "healthier" butterfat that was enhanced by processing of canola. Processing of canola decreased the $\mathrm{C} 16: 0$ to $\mathrm{C} 18$ total fatty acid ratio from 0.48 to $0.36(\mathrm{P}<0.05)$ when compared to heifers receiving the WCS diet.

\section{Conclusion}

There is no need to process canola seed when fed to cows with an intake of around $20 \mathrm{~kg} / \mathrm{d}$ and production of $28-30 \mathrm{~kg} / \mathrm{d}$. At higher intakes ( $>25 \mathrm{~kg} / \mathrm{d}$ ) it might be necessary to process canola due to higher ruminal outflow rates. If the objective is to produce a "healthier" milk fat with reduced C16:C18 total fatty acid ratio, then processing would be necessary.

\section{Acknowledgements}

The authors thank the Protein Research Trust for financial support.

\section{References}

Kennelly, J.J. \& Glimm, D.R.,1998. Can. J. Anim. Sci. 78 (Suppl.), 23.

Macgregor, C., 1994. Directory of feeds and feed ingredients. W.D. Hoard \& Sons, Fort Atkinson, USA.

Schingoethe, D.J., 1995. Proc. $2^{\text {nd }}$ Natl. Alternative Feeds Symp. Univ. Missouri, Columbia. 